\title{
Selected health behaviours of type 2 diabetes patients
}

\begin{abstract}
Introduction. Type 2 diabetes is a chronic disease with an epidemic character. Its prevalence is associated with lifestyle, many environmental factors, and genetic determinants. Implementation of diet therapy is the basis for treatment of the disease.

Aim. The aim of the study was to assess health behaviours and differences in these behaviours in type 2 diabetes patients taking their age into consideration.

Material and methods. The questionnaire survey was carried out among 120 subjects diagnosed with type 2 diabetes. The original questionnaire comprised questions on selected pro-health behaviours, e.g. prophylactic behaviour or self-monitoring in the disease. The statistical analysis was performed on 111 properly completed surveys. The respondents were divided into three age groups: subjects under $60(n=24)$, between 60 and $75(n=64)$, and over 75 years old $(n=23)$.

Results. Regardless of their age, the patients with type 2 diabetes indicated mainly arteriel hypertension as a coexisting complication. The basic element of patients' self-monitoring was checking the blood pressure and glycaemia. Half of the patients declared body weight control, however, a majority were characterised by excessive body weight and abdominal fat deposits, irrespective of their age. Walking was the most popular form of physical activity chosen by the respondents. Regardless of their age, the type 2 diabetes patients exhibited similar readiness for self-education related to their disease.

Conclusions. The surveyed respondents exhibited similar behaviours undertaken to keep healthy. The increase in the regularity of doctor appointments and in the use of pharmacotherapy was closely related to age of the respondents. The advanced age of the respondents had an impact on the regularity of foot inspection. Respondents over 75 years of age adhered to recommendations on the schedule of food and medicine intake, but used diet therapy less frequently.
\end{abstract}

Keywords: health behaviours, type 2 diabetes, age.

DOI: $10.1515 /$ pjph-2017-0033

\section{INTRODUCTION}

Type 2 diabetes is a metabolic disease whose increased incidence accompanies technical, economic, and social development in both developed and developing countries and is a result of a rapid change in lifestyle. Environmental and genetic factors are the determinants of the development of the disease. One of the special contributors to the development of type 2 diabetes is obesity or overweight, i.e. conditions prevalent at present on an epidemic scale. The disease is associated with numerous complications and requires a high level of selfmonitoring on the part of patients $[1,2]$. Nutritional awareness and appropriate health behaviours adopted by patients play a key role in the therapy of type 2 diabetes. A proper selection of products and adherence to the recommendations proposed by doctors or dieticians mitigate the effects of the disease and prevent occurrence of complications. Patient education is aimed at changing eating habits, using carbohydrate exchanges, providing knowledge of the scheme of glycaemia level control as well as normal glycaemia levels, and the ability to use theoretical knowledge in everyday self-monitoring. A fundamental role in the prevention and treatment of type 2 diabetes is an appropriate level of physical activity determining glycaemia control and reduction of excessive body weight [1-3]. Therefore, the comparison of health behaviours among type 2 diabetes patients of all ages seems to be an upto-date and relevant issue.

\section{AIM}

The aim of the study was to assess health behaviours and differences in these behaviours in type 2 diabetes patients, taking their age into consideration.

\section{MATERIAL AND METHODS}

The questionnaire survey was carried out among 120 adult subjects treated in diabetology outpatient clinics in Lublin. Three survey groups were formed according to the patients' age. The first group comprised subjects under 60, the second group was composed of respondents aged between 60 and 75 , and the third group included patients over 75 years old. Two inclusion criteria were adopted: consent to participate in the survey and diagnosed type 2 diabetes. All the subjects were 
self-sufficient in decision making and were characterised by good intellectual and motor skills. The survey was anonymous and voluntary, as emphasised in the questionnaire. The questionnaire included questions on health-beneficial and mainly prophylactic behaviours: adherence to the recommended diet and pharmacotherapy, self-monitoring, and physical activity. Additionally, there were questions concerning the duration of the disease, comorbidities, and sociodemographic data. The questionnaire was prepared and carried out in accordance with the rules for questionnaire data collection [4].

The results obtained in 111 correctly completed questionnaires $(7.5 \%$ were discarded) were expressed as percentages of responses given within the age groups (group I $n=24$; group II $n=64$; group III $n=23)$ and as means and medians $\left(Q_{2}\right)$. They were statistically analysed using the Statistica version 13 computer program (Dell Inc. 2016). Quantitative variables were analysed with the ANOVA variance analysis with age as a discriminating factor. Qualitative variables were analysed with Pearson's $\chi^{2}$ test (Yates correction was applied in justified cases). Cramér's V contingency ratio was calculated to determine the strength of the correlations between the age and the assessed variables. The value of $\alpha=0.05$ was assumed as the level of significance (significant differences at $\mathrm{p}<0.05$ ) $[5]$.

\section{RESULTS}

The average age of all the subjects was 64 years and the mean duration of the disease reported by the patients was 12.7 years. Females and males represented $62 \%$ and $38 \%$ of the respondents, respectively. The largest group was constituted by respondents between 60 and 75 years of age (group II), mean age -68 years, $\left(Q_{2}=69.5\right.$ years $)$, who had been affected by type 2 diabetes for 14 years on average $\left(Q_{2}=10\right.$ years). The mean age of the subjects in group I was 39.8 years $\left(Q_{2}=36\right.$ years); they have suffered from diabetes for 7 years $\left(Q_{2}=5\right.$ years). The last group of patients were approx. 77 years old $\left(Q_{2}=76\right.$ years $)$ and the duration of the disease was 15 years $\left(Q_{2}=13\right.$ years $)$. The nutrition status of the respondents estimated with BMI was differentiated according to the age groups $(\mathrm{p}=0.003)$ and its mean values were $32 \mathrm{~kg} / \mathrm{m} 2\left(\mathrm{Q}_{2}=28.6 \mathrm{~kg} / \mathrm{m} 2\right)$ in the youngest group (group I - below 60 years of age), approx. $27.5 \mathrm{~kg} / \mathrm{m} 2$ $\left(\mathrm{Q}_{2}=28.7 \mathrm{~kg} / \mathrm{m} 2\right)$ in the oldest group (group III over 75 years of age), and approx. $29.1 \mathrm{~kg} / \mathrm{m} 2\left(\mathrm{Q}_{2}=33.9 \mathrm{~kg} / \mathrm{m} 2\right)$ in group II (from 60 to 75 years of age). The Waist to Hip Ratio (WHR) value, i.e. $0.96\left(\mathrm{Q}_{2}=0.96 ; \mathrm{p}=0.702\right)$ was calculated based on the measurement of waist and hip circumference, which was approx. $103 \mathrm{~cm}$ and $108 \mathrm{~cm}$ in all the respondents $(p=0.213$; $\mathrm{p}=0.166$ ). Over half of the respondents declared having secondary education. Every fifth respondent had vocational or higher education, and only $4 \%$ had primary education. A vast majority of the surveyed subjects (73\%) were disability pensioners or old-age pensioners. Other respondents were professionally active as manual (16\%) and non-manual (11\%) workers.

Table 1 presents information on the occurrence and type of complications in patients with type 2 diabetes. The highest proportion of the respondents indicated co-occurrence of hypertension $-59 \%(\mathrm{p}=0.660)$. Almost every fourth subject suffered from diabetic neuropathy $-23 \%(\mathrm{p}=0.177)$, whereas diabetic nephropathy was reported by approx. $13 \%$ of the respondents $(p=0.167)$. No co-occurring complications were declared by over one fifth of the type 2 diabetic patients $(\mathrm{p}=0.075)$. Patients' age had a significant impact only on the development of the diabetic foot syndrome $(p=0.043)$, which affected the group of the youngest and oldest participants in the study with significantly higher frequency.

TABLE 1. Occurrence and type of complications associated with type 2 diabetes reported by the respondents.

\begin{tabular}{|c|c|c|c|c|c|c|c|}
\hline \multirow[b]{2}{*}{ Variables } & \multicolumn{3}{|c|}{ Age categories } & \multirow[b]{2}{*}{ 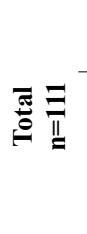 } & \multicolumn{3}{|c|}{$\begin{array}{c}\text { Statistics } \\
\text { parameters }\end{array}$} \\
\hline & 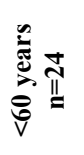 & 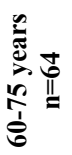 & 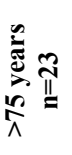 & & $x$ & 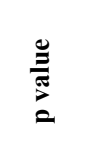 & 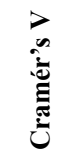 \\
\hline arterial hy & 66.7 & 56.3 & 56.5 & 58.6 & 0.83 & 0.660 & 0.086 \\
\hline diabetic neuropathy & 16.7 & 25.0 & 26.1 & 23.4 & 3.48 & 0.176 & 0.177 \\
\hline no diabetic complications & 16.7 & 21.9 & 26.1 & 21.6 & 0.62 & 0.733 & 0.075 \\
\hline diabetic nephropathy & 8.3 & 17.2 & 4.4 & 12.6 & 3.04 & 0.219 & 0.165 \\
\hline diabetic retinopathy & 0.0 & 10.9 & 4.4 & 7.2 & 3.48 & 0.176 & 0.177 \\
\hline coronary artery disease & 8.3 & 7.8 & 4.4 & 7.2 & 0.36 & 0.835 & 0.057 \\
\hline diabetic foot syndrome & 8.3 & 6.3 & 8.7 & 7.2 & 0.21 & 0.901 & 0.043 \\
\hline polyneuroangiopathy & 8.3 & 1.6 & 0.0 & 2.7 & 3.85 & 0.146 & 0.186 \\
\hline
\end{tabular}

Over half of the respondents declared regular insulin intake (Table 2). The age had a significant effect on the application of pharmacological therapy $\left(\chi^{2}=7.78 ; \mathrm{p}=0.020\right)$. The strength of the relationship between the choice of this answer and the respondents' age was weak $(\mathrm{V}=0.265)$. The respondents most often indicated that they monitored blood pressure $(\mathrm{p}=0.807)$. A majority of respondents who declared foot inspection were over 75 years old $(p=0.020)$. A vast majority of patients attended medical appointments, which was $100 \%$ in the case of the oldest group $(\mathrm{p}=0.028)$. Most respondents $(74 \%)$ declared that they followed doctor's/dietician's recommendations on the fixed schedule of food and medicine intake $(p=0.173)$, but only $30 \%$ of the oldest group used the recommended food therapy $(\mathrm{p}=0.006)$. The strength of the relationship between the choice of this answer and the respondents' age was moderate $(\mathrm{V}=0.302)$. Carbohydrate exchanges were calculated by less than $11 \%$ of the total number of patients $(p=0.799)$. Almost half of the respondents acknowledged the need for self-education about type 2 diabetes $(p=0.124)$. To verify and update their knowledge about the disease, half of them read specialist books and guides about the disease, while definitely fewer respondents $(16 \%)$ attended training on the disease $(\mathrm{p}=0.093)$.

Glycaemia was regularly monitored by over $60 \%$ of the type 2 diabetes patients, whereas every fourth subject controlled the glucose level irregularly $(\mathrm{p}=0.123$ ) (Table 3$)$. The respondents most frequently declared that they checked fas -ting glycaemia $-82 \%(\mathrm{p}=0.547)$. The subjects over 75 years of age measured the level of glucose with a significantly higher frequency than the younger patients, i.e. before the main meals and before sleep $(\mathrm{p}<0.05)$. The strength of the relationship with age was low.

Walking was pointed out as the most frequent form of physical activity by the type 2 diabetes patients (Figure 1). In each age category, over $60 \%$ of the respondents chose this form of physical activity $(\mathrm{p}=0.358)$. Half of the subjects in the group of over 75-year-olds indicated housework as a form of physical 
TABLE 2. Monitoring of selected indicators of health status, compliance with medical recommendations, and self-education in type 2 diabetes patients.

\begin{tabular}{|c|c|c|c|c|c|c|c|c|}
\hline \multirow{2}{*}{\multicolumn{2}{|c|}{ Variables }} & \multicolumn{3}{|c|}{ Age categories } & \multirow[b]{2}{*}{$\begin{array}{c}\text { Total } \\
\mathrm{n}=111\end{array}$} & \multicolumn{3}{|c|}{ Statistics parameters } \\
\hline & & $\begin{array}{c}<60 \text { years } \\
\mathbf{n}=\mathbf{2 4}\end{array}$ & $\begin{array}{c}60-75 \text { years } \\
n=64\end{array}$ & $\begin{array}{c}>75 \text { years } \\
n=23\end{array}$ & & $\chi^{2}$ & p value & $\begin{array}{c}\text { Cramér's } \\
\text { V }\end{array}$ \\
\hline \multicolumn{2}{|l|}{ Pharmacotherapy } & 33.3 & 51.6 & 73.9 & 52.3 & 7.78 & 0.020 & 0.265 \\
\hline \multirow{3}{*}{ Scope of self-monitoring } & blood pressure monitoring & 75.0 & 79.7 & 82.6 & 79.3 & 0.43 & 0.807 & 0.062 \\
\hline & body weight control & 50.0 & 51.6 & 39.1 & 48.7 & 1.07 & 0.586 & 0.098 \\
\hline & foot inspection & 25.0 & 42.2 & 65.2 & 43.2 & 7.81 & 0.020 & 0.265 \\
\hline \multicolumn{2}{|l|}{ Regular medical appointments } & 75.0 & 89.1 & 100.0 & 88.3 & 7.19 & 0.028 & 0.254 \\
\hline \multirow{3}{*}{$\begin{array}{l}\text { Following doctor's/dietician's } \\
\text { recommendations }\end{array}$} & $\begin{array}{l}\text { adherence to the recommended } \\
\text { diet }\end{array}$ & 66.7 & 67.2 & 30.4 & 59.5 & 10.14 & 0.006 & 0.302 \\
\hline & calculation of CE & 8.3 & 12.5 & 8.7 & 10.8 & 0.45 & 0.799 & 0.064 \\
\hline & $\begin{array}{l}\text { fixed schedule of food } \\
\text { and medicine intake }\end{array}$ & 83.3 & 67.2 & 82.6 & 73.9 & 3.50 & 0.173 & 0.178 \\
\hline \multicolumn{2}{|c|}{ Awareness of the need for self-education about diabetes } & 58.3 & 51.6 & 30.4 & 48.7 & 4.17 & 0.124 & 0.194 \\
\hline \multirow{3}{*}{ Forms of self-education } & $\begin{array}{l}\text { I attend training } \\
\text { about my disease }\end{array}$ & 8.3 & 14.1 & 30.4 & 16.2 & 4.73 & 0.093 & 0.206 \\
\hline & $\begin{array}{l}\text { I read books/guides } \\
\text { on my disease }\end{array}$ & 58.3 & 48.4 & 39.1 & 48.7 & 1.74 & 0.419 & 0.125 \\
\hline & $\begin{array}{l}\text { I am not interested } \\
\text { in self-education }\end{array}$ & 0.0 & 0.0 & 4.4 & 0.9 & 3.86 & 0.145 & 0.186 \\
\hline
\end{tabular}

TABLE 3. Regularity and time of glycaemia monitoring by the respondents.

\begin{tabular}{|c|c|c|c|c|c|c|c|c|}
\hline \multirow{2}{*}{\multicolumn{2}{|c|}{ Variables }} & \multicolumn{3}{|c|}{ Age categories } & \multirow{2}{*}{$\begin{array}{c}\text { Total } \\
\mathbf{n}=111\end{array}$} & \multicolumn{3}{|c|}{ Statistics parameters } \\
\hline & & $\begin{array}{c}<60 \text { years } \\
n=24\end{array}$ & $\begin{array}{c}60-75 \text { years } \\
n=64\end{array}$ & $\begin{array}{c}>75 \text { years } \\
n=23\end{array}$ & & $\chi^{2}$ & p value & $\begin{array}{c}\text { Cramér's } \\
\text { V }\end{array}$ \\
\hline \multirow{4}{*}{$\begin{array}{l}\text { Monitoring blood glycaemia } \\
\text { with a glucose meter }\end{array}$} & regularly & 50.0 & 64.1 & 82.6 & 64.9 & \multirow{4}{*}{10.05} & \multirow{4}{*}{0.123} & \multirow{4}{*}{0.213} \\
\hline & irregularly & 33.3 & 25.0 & 17.4 & 25.2 & & & \\
\hline & only when I feel bad & 16.7 & 6.3 & 0.0 & 7.2 & & & \\
\hline & no measurement & 0.0 & 4.7 & 0.0 & 2.7 & & & \\
\hline \multirow{5}{*}{$\begin{array}{l}\text { Time of blood glycaemia } \\
\text { monitoring }\end{array}$} & fasting & 75.0 & 82.8 & 87.0 & 82.0 & 1.21 & 0.547 & 0.104 \\
\hline & after a meal & 58.3 & 64.1 & 43.5 & 58.6 & 2.95 & 0.228 & 0.163 \\
\hline & before the main meals & 33.3 & 46.9 & 69.6 & 48.7 & 6.36 & 0.042 & 0.239 \\
\hline & when I feel bad & 41.7 & 39.1 & 39.1 & 39.6 & 0.05 & 0.974 & 0.022 \\
\hline & before sleep & 16.7 & 35.9 & 52.2 & 35.1 & 6.54 & 0.038 & 0.243 \\
\hline
\end{tabular}

activity ( $\mathrm{p}=0.024)$; however, the strength of the age effect was moderate $(\mathrm{V}=0.304)$. Other types of physical activity than those mentioned in the questionnaire were more often indicated by patients aged below $60(p<0.001)$. These activities included dancing, football, and gardening, and the strength of the relationship of the choice with age was moderate $(\mathrm{V}=0.412)$.

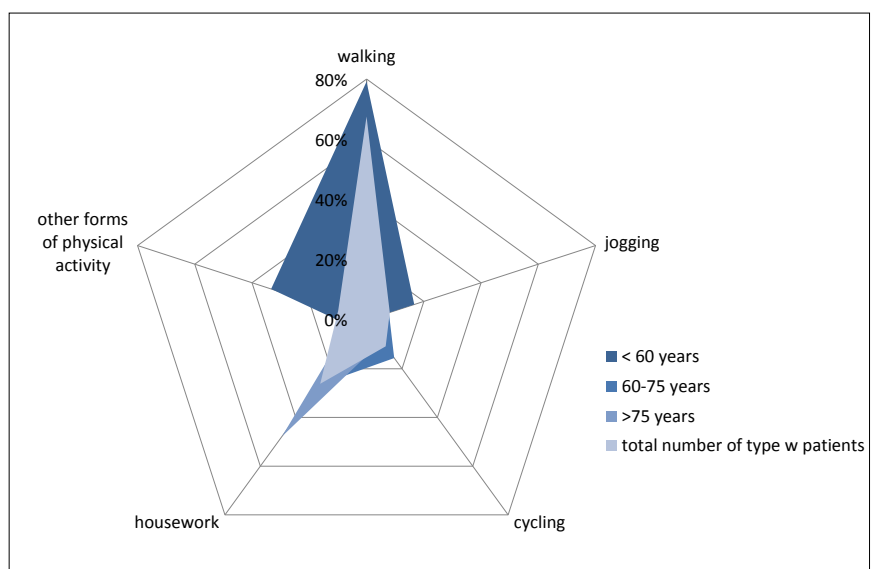

FIGURE 1. Forms of physical activity undertaken by type 2 diabetes patients.

\section{DISCUSSION}

Type 2 diabetes is one of the most common diet-related non-infectious diseases. In Poland, approximately 2.6 million people suffer from diabetes, with type 2 diabetes accounting for the highest percent. The incidence of this disease increases with age, and the greatest number of patients are over 50 years old [6]. In the present study, over 60 -year-old patients constituted the biggest group with the longest duration of the disease. Diabetes is characterised by many serious complications, which can reduce life expectancy by $10-15$ years when not controlled. Untreated or incorrectly treated diabetes results in changes in the capillaries causing visual disturbances, disorders of blood supply to the lower extremities, and kidney damage. The co-occurring diabetic foot syndrome may affect $4-10 \%$ of patients and neuropathies are diagnosed in $10-90 \%$ [7].

In the present study, more than half of the respondents indicated hypertension, and the diabetic foot syndrome affected nearly every ninth patient before the age of 60 and after the age of 75. This may be associated with the insufficient frequency of foot inspection in the younger patient group and with the severity and duration of the disease in the older group. As shown by Kurowska and Nowakowska [8], 95\% and 99\% of respondents with type 2 diabetes before and after training 
in diabetes management indicated the diabetic foot syndrome to be a symptom requiring self-monitoring.

Araszkiewicz et al. [2] reported that $62 \%$ of 54-year-old patients with an average 9-year duration of the disease use insulin. In the present study, there was a significant effect of age on the application of pharmacological therapy. A majority of the respondents $(65 \%)$ declared that they measured glucose levels regularly. The over 75-year-old patients checked the glycaemia status before the main meals and before sleep at a significantly higher frequency $(\mathrm{p}<0.05)$. In their study, Dudzińska et al. [9] reported that type 2 diabetes patients measuring daily glycaemia accounted for $73 \%$.

One of the most important factors triggering the development of type 2 diabetes is excessive body weight and increased abdominal fat and visceral fat tissue deposits. The present study has demonstrated that the surveyed patients in all age categories had excessive body weight and increased abdominal fat deposits. Similar results were obtained by Włodarek and Głąbska [10], who reported a BMI value of $29.9 \mathrm{~kg} / \mathrm{m}^{2}$ in the examined population of type 2 diabetes patients. The key issue in the treatment of type 2 diabetes is modification of the lifestyle, including eating habits, as well as increased physical activity and normalisation of body weight $[1,6]$.

A vast majority of the patients (74\%) surveyed in this study had meals and took medicines at a fixed time of the day in accordance with doctor's/dietician's recommendations. This is probably related to the awareness of the consequences of non-compliance. Investigations conducted by Kurowska and Frąckowiak [11] demonstrated that 97\% of type 2 diabetes patients knew the consequences of not taking medications and $80 \%$ adhered to dietary recommendations. However, it was found in this study that only approx. $60 \%$ of the patients declared adherence to the recommended diet, and this percent was significantly lower in the group over 75 years of age $(p<0.01)$. Calculation of carbohydrate exchanges was declared by every tenth respondent. Mędrela-Kuder and Bis [1] showed that this form of diet monitoring was declared by a substantially greater number of type 2 diabetes patients, i.e. $48 \%$ of respondents.

According to the current recommendations of the Polish Diabetes Association, education is a permanent, integral, and indispensable element in diabetes therapy [6]. The results obtained in the present study show that every second patient acknowledged the need for self-education and used books and guides to broaden, verify, and update their knowledge of the disease. In turn, Araszkiewicz et al. [2] reported that $33 \%$ of respondents with type 2 diabetes attended educational training about type 2 diabetes.

Type 2 diabetes therapy is inextricably associated with adequate physical activity, which promotes maintenance of not only normal body weight but also glycaemia. Type 2 diabetes patients are advised to take a moderate aerobic effort with the length of exercise of approximately 30 minutes [6]. Walking was the most popular form of physical activity chosen by the respondents (over 60\%). Similar results in a group of middleaged type 2 diabetes patients were reported by Mędrela-Kuder and Bis [1], i.e. $85 \%$ of males and $75 \%$ of females declared walking as their physical activity. Szypnicka and Sińska [12] demonstrated that $22 \%$ of respondents were unaware of the contribution of regular physical activity to maintenance of normal blood glucose concentration. Appropriate systematic physical exercise has a beneficial effect on the body weight and influences the utilisation of energy substrates. Additionally, it improves insulin sensitivity and has a positive impact on other metabolic dysfunctions [13].

\section{CONCLUSIONS}

1. The respondents exhibited similar health behaviours undertaken for maintaining their health.

2. Irrespective of their age, the type 2 diabetes patients declared similar readiness for self-education related to their disease.

3. Checking blood pressure and glycaemia was the basic element of self-monitoring declared by the patients.

4. Although half of the patients declared weight control, they were characterised by excessive body weight and abdominal fat tissue deposits, regardless of their age.

5. Systematic doctor appointments and the use of pharmacotherapy were closely related to the age of the respondents. Additionally, the advanced age of the respondents had an influence on the regularity of foot inspection.

6. Patients over 75 years of age adhered to the recommended schedule of food and medicine intake, but used the recommended diet therapy less frequently.

\section{REFERENCES}

1. Mędrela-Kuder E, Bis H. Porównanie aktywności fizycznej i diety u kobiet i mężczyzn chorych na cukrzycę typu 2. Med Ogólna Nauki Zdr. 2014;20(1):31-3.

2. Araszkiewicz A, Piasecka D, Wierusz-Wysocka B. Ocena wiedzy pacjentów z typem 2 cukrzycy na temat przewlekłych powikłań choroby. Now Lek. 2012;81(2):158-63.

3. Świrska J, Fedurek D, Zwolak A. The knowledge of dietary rules among patients with diabetes. J Educ Health Sport. 2017;7(5):419-35. doi http:// dx.doi.org/10.5281/zenodo.800717

4. Stupnicki R. Analiza i prezentacja danych ankietowych. Warszawa: Wyd Akademia Wychowania Fizycznego; 2003.

5. Stanisz A. Przystępny kurs statystyki na przykładach z medycyny z wykorzystaniem programu Statistica. Kraków: Statsoft; 2006.

6. PTD, Zalecenia kliniczne dotyczące postępowania u chorych na cukrzycę 2017. Stanowisko Polskiego Towarzystwa Diabetologicznego. Diabetol Prakt. 2017;3(A):1-82.

7. Kalinowski P, Bojakowska U, Kowalska M.E. Ocena wiedzy pacjentów o powikłaniach cukrzycy. Med Ogólna Nauki Zdr. 2012;18(4):302-7.

8. Kurowska K, Nowakowska K. Poczucie koherencji a stan posiadanej wiedzy o chorobie u osób z rozpoznaniem cukrzycy typu 2. Diabetol Prakt. 2011;12(2):71-7.

9. Dudzińska M, Tarach JS, Malicka J, et al. Assessment of changes in self-control among patients with type 2 diabetes after the introduction of insulin therapy - a prospective study. Fam Med Primary Care Rev. 2013;15(3):315-7.

10. Włodarek D, Głąbska D. Zwyczaje żywieniowe osób chorych na cukrzycę typu 2. Diabetol Prakt. 2010;11(1):17-23.

11. Kurowska K, Frąckowiak M. Wsparcie społeczne a radzenie sobie w przewlekłej chorobie na przykładzie cukrzycy typu 2. Diabetol Prakt 2010;11(3):101-7.

12. Szypnicka M, Sińska B. Ocena wpływu wiedzy pacjentów o żywieniu na skuteczność leczenia dietetycznego cukrzycy. Med Metab. 2013;17(3):35-40.

13. Zielke M, Reguła J. Sposób żywienia i aktywność fizyczna a wskaźniki antropometryczne chorych na cukrzycę typu 2. Żyw Człow Metab. 2007;34:1122-6.

Corresponding author

Dr Wioletta Samolińska

Department of Bromatology and Nutrition Physiology

Institute of Animal Nutrition and Bromatology

University of Life Sciences

13 Akademicka St., 20-950 Lublin, Poland

E-mail: wioletta.samolinska@up.lublin.pl

tel. $(+4881) 4456914$ 